\title{
HUBUNGAN KETERAMPILAN SOSIAL DENGAN MOTIVASI BELAJAR SISWA
}

\author{
Yayan Alpian, Ranti Mulyani \\ University of Buana Perjuangan Karawang, Indonesia \\ yayan.alpian@ubpkarawang.ac.id
}

\begin{abstract}
Problems that occur in the scope of basic education include many students who cannot understand each other's opinions, lack understanding of the needs of peers, teachers, and people around them, children have low social skills and attitudes, lack trust in caring towards other people, interactions that are less pleasant, less confident, rarely communicate with others, and cause discomfort during the learning process because there is no external motivation that supports and has an impact on learning motivation that is less than the maximum. This research is motivated by the low motivation of students in learning, the relationship of interaction with the environment is not good, not optimal use of learning methods. the purpose of this study was to determine the relationship between social skills and learning motivation of fifth-grade students at Nagasari Elementary School in West Karawang District. This research is a type of quantitative correlation research. Data analysis technique to test the hypothesis is done by calculating the product-moment correlation statistics. The results of hypothesis testing, there is a relationship between social skills and student motivation. This was obtained $t_{\text {count }} 6.933>t_{\text {table }} 1.989$ and $r_{x y} 0.606$ with a significance of 0.05 and $n=85$ indicating that the hypothesis was accepted. From the results of this study, it can be concluded that social skills and student motivation have a strong relationship.
\end{abstract}

Keywords: social skills, learning motivation

\begin{abstract}
Abstrak
Masalah yang terjadi di ruang lingkup pendidikan dasar diantaranya adalah banyak siswa yang belum bisa memahami pendapat siswa satu sama lain, kurang mengerti tentang kebutuhan teman sebaya, guru, dan orang-orang disekitarnya, anak mempunyai keterampilan dan sikap sosial rendah, kurang memiliki rasa percaya peduli terhadap orang lain, interaksi yang kurang menyenangkan, kurang percaya diri, jarang melakukan komunikasi dengan orang lain, dan menimbulkan ketidaknyamanan saat terjadi proses pembelajaran karena tidak ada motivasi eksternal yang mendukung dan berdampak pada motivasi belajar yang kurang maksimal. Penelitian ini bertujuan untuk mengetahui hubungan antara keterampilan sosial dengan motivasi belajar siswa kelas V di SDN Gugus Nagasari Kecamatan Karawang Barat. Penelitian ini merupakan jenis penelitian kuantitatif korelasi. Teknik analisis data untuk menguji hipotesis dilakukan dengan perhitungan statistik korelasi product moment. Hasil pengujian hipotesis, terdapat hubungan antara keterampilan sosial dengan motivasi belajar siswa. Hal ini diperoleh $t_{\text {hitung }} 6,933>t_{\text {tabel }} 1,989$ dan $r_{-} x y$ 0,606 dengan signifikan 0,05 dan $\mathrm{n}=85$ menunjukan bahwa hipotesis diterima. Dari hasil penelitian ini dapat disimpulkan bahwa keterampilan sosial dan motivasi belajar siswa memiliki hubungan yang kuat.
\end{abstract}

Kata Kunci: keterampilan sosial, motivasi belajar

\begin{tabular}{llll}
\hline Received & $: 2019-12-17$ & Approved & $: 2019-12-27$ \\
Reviesed & $: 2019-12-26$ & Published & $: 2019-12-30$ \\
\hline
\end{tabular}

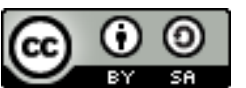

Jurnal Cakrawala Pendas is licensed under a Creative Commons AttributionShareAlike 4.0 International License.

\section{Pendahuluan}

Pendidikan merupakan suatu bentuk investasi jangka panjang yang penting bagi seorang manusia, karena pendidikan bertujuan untuk membantu manusia dalam meningkatkan potensinya. Di era globalisasi seperti saat ini, masyarakat Indonesia mulai sadar dalam pentingnya pendidikan. Pendidikan diharapkan dapat meningkatkan kualitas 
Sumber Daya Manusia untuk meraih tujuan pendidikan nasional. Dalam proses pencapaian tujuan pendidikan nasional diperlukan motivasi belajar dari diri siswa agar pendidikan yang diberikan kepada siswa dapat diterima dengan baik, maksimal, dan berlangsung secara efektif dan efisien. Adanya motivasi belajar yang baik akan mendorong diri siswa dalam menerapkan perilaku belajar kearah tujuan yang ingin dicapai berupa hasil belajar yang baik.

Menurut Winarni (2006: 2) "Motivasi belajar adalah dorongan dari dalam diri individu baik disadari maupun tidak disadari untuk melakukan perilaku belajar ke arah suatu tujuan yang ingin dicapai yakni prestasi belajar". Tingkat intensitas motivasi ini selain dipengaruhi oleh faktor dari dalam diri, juga dipengaruhi oleh lingkungan di sekitar individu yang bersangkutan. Semakin baik dukungan sekitar terhadap perilaku tertentu, maka semakin kuat motivasi yang terbentuk untuk melakukan perilaku tersebut.

Berdasarkan studi pendahuluan dilakukan pada siswa kelas V SDN se-Gugus Nagasari Kecamatan Karawang Barat siswa yang belum bisa memahami pendapat siswa satu sama lain, kurang mengerti tentang kebutuhan teman sebaya, guru, dan orang-orang disekitarnya, anak mempunyai keterampilan dan sikap sosial rendah, kurang memiliki rasa percaya peduli terhadap orang lain, interaksi yang kurang menyenangkan, kurang percaya diri, jarang melakukan komunikasi dengan orang lain, dan menimbulkan ketidaknyamanan saat terjadi proses pembelajaran karena tidak ada motivasi dari luar yang mendukung. Oleh karena itu, untuk membentuk motivasi belajar agar lebih kuat, maka harus ada stimulus dari luar yang dapat memacu siswa dalam mencapai kesuksesan, dalam hal ini diantaranya keterampilan sosial.

Keterampilan sosial termasuk keterampilan yang perlu dikembangkan karena berkaitan dengan hubungan antar siswa. Karena keterampilan sosial dibutuhkan dalam kehidupan setiap manusia untuk berinteraksi dengan lingkungan masyarakat terlebih keterampilan sosial perlu dimiliki oleh siswa sebagai modal dasar untuk berinteraksi dengan teman sebayanya dilingkungan dimana tempat siswa menuntut ilmu yaitu sekolah. Hal ini sejalan dengan pendapat Listyaningrum (2016: 1485) yang menyatakan bahwa "Keterampilan sosial adalah keterampilan primer yang perlu dimiliki oleh setiap individu untuk menciptakan komunikasi efektif baik verbal dan nonverbal kepada individu yang lain".

Keterampilan sosial yang harus dimiliki oleh siswa meliputi keterampilan berkomunikasi yang baik secara lisan maupun tertulis dan kecakapan bekerja sama dengan orang lain, baik dalam kelompok kecil maupun kelompok besar dalam proses interraksi dalam proses pembelajaran disekolah. Siswa yang memiliki keterampilan sosial yang baik dapat membina hubungan baik diantara teman-temannya maupun orang-orang disekitarnya sehingga jika memiliki hubungan yang baik dengan teman sebaya maka intensitas motivasi belajarpun akan meningkat.

Siswa yang memiliki keterampilan sosial melakukan interaksi dengan saling berkomunikasi, berinteraksi dan menjalin kerjasama dalam kelompok serta menjalin hubungan baik dengan orang lain. Keterampilan sosial timbul karena manusia merupakan makhluk sosial, maka keterampilan merupakan kebutuhan penting yang wajib dikembangkan karena berkaitan dengan hubungan antar siswa. Menurut Listaningrum (2016: 1485) mengungkapkan bahwa "keterampilan sosial merupakan salah satu keterampilan hidup yang harus dajarkan kepada anak sejak dini". Sedangkan menurut Parji (2016: 16) "Keterampilan sosial meliputi keterampilan berkomunikasi, baik secara lisan maupun tertulis dan kecakapan bekerja sama dengan orang lain, baik dalam kelompok kecil maupun kelompok besar". Siswa 
yang memiliki keterampilan sosial yang baik dapat membina hubungan baik diantara temantemannya maupun orang-orang disekitarnya.

Menurut Matson dan Ollendick (Budiarto, 2016: 513) menyatakan bahwa "keterampilan sosial adalah kemampuan seseorang dalam beradaptasi secara baik dengan lingkungannya dan menghindari konflik saat berkomunikasi baik secara fisik maupun verbal". Dengan demikian, sebagai makhluk sosial manusia selalu melakukan interaksi baik interaksi dalam bentuk verbal maupun nonverbal, langsung maupun tidak langsung, secara lisan maupun tertulis. Kaitanya dengan interaksi sosial, manusia memerlukan kemampuan keterampilan sosial untuk memperlancar interaksi dengan sesamanya.

"Keterampilan sosial adalah kemampuan berkomunikasi, bekerjasama, berbagi, berpartisipasi, dan beradaptasi berupa simpati, empati dan mampu memecahan masalah serta disiplin sesuai dengan peraturan dan norma yang berlaku" (Perdani, 2013: 338). Kemampuan berkomunikasi yang dimaksud adalah perilaku yang dipelajari dan digunakan individu dalam situasi interpersonal untuk memperoleh pengukuhan dari lingkungannya. Dengan demikian, keterampilan sosial bukan kemampuan yang dibawa sejak lahir tetapi diperoleh melalui proses belajar, baik belajar dari orang tua sebagai figur yang paling dekat dengan anak maupun belajar dari teman sebaya dan lingkungan masyarakat.

Sejalan dengan Cartledge \& Milburn (1992: 6) menyatakan bahwa keterampilan sosial merupakan kemampuan seseorang atau warga masyarakat dalam mengadakan hubungan dengan orang lain dan kemampuan memecahkan masalah, sehingga dapat beradaptasi secara harmonis dengan masyarakat di sekitarnya. Keterampilan sosial merupakan istilah bagi kemampuan untuk berhubungan dengan lingkungan sosial secara sesuai. Menurut Suharmini (2017: 12) keterampilan sosial tampak pada sikap dan perilaku keseharian, seperti kemampuan berkomunikasi; menyesuaikan diri, keterlibatan dalam kelompok, mengatasi masalah, dan mengembangkan potensi diri dalam konteks lingkungan.

Jarolimek (Perdani, 2013: 338) menyatakan bahwa keterampilan sosial meliputi beberapa aspek, diantanya adalah: (1) Keterampilan hidup bersama dan bekerja sama, mampu menempatkan diri dalam lingkungan sosial, menghargai orang lain; (2) keterampilan untuk belajar menggunakan kontrol diri dan kontrol social; serta (3) keterampilan untuk saling bertukar pikiran dan pengalaman dengan orang lain.

Kurangnya keterampilan sosial akan berdampak pada motivasi belajar siswa karena keterampilan sosial cukup erat kaitannya dengan berbagai kemampuan lainnya seperti menjalin kerjasama dalam kelompok, berinteraksi dengan sebayanya, bergabung dalam kelompok, menjalin pertemanan baru, menangani konflik, dan belajar bekerja sama. Keterampilan sosial memiliki indicator sebagai tolak ukur untuk mengetahui siswa memiliki keterampilan sosial atau tidak. Menurut Suharmini (2017: 19) indikator keterampilan sosial diantaranya: 1) Bekerjasama dengan semua teman, 2). Bekerjasama untuk hal yang positif, 3) Berinteraksi dengan teman, 4) Tidak menghindari guru atau orang dewasa lain, 5) Terlibat dalam kegiatan berkelompok, 6) Mau berkomunikasi timbal balik secara verbal dan atau nonverbal, 7) Mau memulai komunikasi dengan teman, 8) Sopan dalam berbicara dan atau berperilaku, 9) Tidak memilih-milih teman, 10) Diterima oleh lingkungan (teman, sekolah).

Salah satu cara agar seseorang untuk mau belajar dan mengembangkan pengetahuan adalah dengan cara menumbuhkan motivasi belajar. Siswa akan terdorong untuk belajar jika mereka memiliki motivasi untuk belajar. Menurut Sudarwan (Suprihatin, 2015: 74) "motivasi diartikan sebagai kekuatan, dorongan, kebutuhan, semangat yang mendorong seseorang atau sekelompok orang untuk mencapai prestasi tertentu sesuai dengan apa yang dikehendakinya". 
Dorongan ini berada pada diri seseorang yang menggerakkan untuk melakukan sesuatu yang sesuai dengan dorongan dalam dirinya. Maka dari itu, perbuatan seseorang yang didasarkan atas motivasi tertentu mengandung makna sesuai dengan motivasi yang mendasarinya. Sejalan dengan Palupi (2014: 158) "Motivasi adalah suatu proses untuk menggiatkan motif menjadi perbuatan atau tingkah laku untuk memenuhi kebutuhan dan mencapai tujuan tertentu". Maka dari itu motivasi diartikan sebagai keseluruhan daya penggerak dalam diri siswa untuk melakukan serangkaian kegiatan belajar guna mencapai tujuan yang telah ditetapkan.

Motivasi bagaikan motor penggerak dalam perbuatan yang diaplikasikan dalam tingkah laku, sehingga siswa yang memiliki motivasi akan tergerak untuk memulai belajar (Suranto, 2015:12). Dorongan tersebut mengarahkan perilaku seseorang untuk aktif bertindak dalam rangka mencapai suatu tujuan yang ingin dicapainya. Hal ini diperkuat oleh Gray (Suprihatin 2015: 75) "motivasi merupakan sejumlah proses yang bersifat internal atau eksternal bagi individu, yang menyebabkan timbulnya sikap antusias dalam hal melaksanakan kegiatan-kegiatan tertentu". Sikap antusias yang dimaksud adalah dorongan untuk melakukan kegiatan belajar yang sangat tinggi.

Melalui motivasi diharapkan siswa memiliki usaha untuk membangun kondisi sehingga memiliki keinginan dan minat serta bersedia melakukan sesuatu. Perilaku yang termotivasi adalah perilaku yang penuh energi, terarah dan bertahan lama. Motivasi belajar sangat diperlukan siswa dalam kegiatan belajar mengajar untuk mencapai tujuan belajar. Seseorang siswa yang memiliki motivasi belajar yang tinggi pada mata pelajaran apapun akan belajar dengan sungguh-sungguh, dan tidak mudah menyerah dan terus berusaha mencapai hasil belajar yang baik. Sedangkah siswa yang memiliki motivasi belajar yang rendah akan cepat menyerah apabila terdapat kesulitan. Adanya motivasi yang tinggi dari siswa diharapkan mampu menggerakkan minat siswa untuk menjadikan sekolah bukan hanya sebagai tuntutan namun juga merupakan kebutuhan bagi dirinya.

Konsep motivasi yang berhubungan dengan tingkah laku seseorang dapat diklasifikasi sebagai berikut: (1) seseorang senang terhadap sesuatu, apabila ia dapat mempertahankan rasa sanangnya maka akan termotivasi untuk melakukan kegiatan itu, dan (2) apabila seseorang merasa yakin dan mampu mengahadapi tantangan maka biasanya orang tersebut terdorong melakukan kegiatan tersebut (Uno, 2016: 8). Ada beberapa peranan penting dari motivasi belajar dan pembelajaran, menurut Uno (2016: 27) "peranan motivasi belajar diantanya: (1) menentukan hal-hal yang dapat dijadikan penguat belajar, (2) memperjelas tujuan belajar yang hendak dicapai, (3) menentukan ragam kendali terhadap rangsangan belajar, (4) menentukan ketekunan belajar". Seberapa kuat motivasi yang dimiliki individu akan banyak menentukan kualitas perilaku yang ditampilkannya, baik dalam belajar, bekerja maupun dalam kehidupan lainnya.

Motivasi belajar dapat muncul apabila siswa memiliki keinginan untuk belajar yang tinggi yang didorong oleh faktor intrinsik maupun ekstrinsik yang ada pada diri siswa sehingga tujuan pembelajaran yang sudah dirumuskan dapat tercapai secara optimal. Dengan demikian motivasi berfungsi sebagai pendorong usaha dan pencapaian prestasi. Adanya motivasi yang baik dalam belajar akan menunjukkan hasil yang baik. Selanjutnya menurut Winarsih (Kompri 2015: 237) ada tiga fungsi motivasi yaitu: a) mendorong manusia untuk berbuat, jadi sebagai penggerak yang melepaskan energi. b) menentukan arah perbuatan kearah yang ingin dicapai. c) menyeleksi perbuatan, yakni menentukan perbuatan-perbuatan apa yang harus dikerjakan guna mencapai tujuan. Hal ini didukung oleh Asy'ari (2014: 85) 
Motivasi belajar adalah suatu dorongan kehendak yang menyebabkan seseorang melakukan suatu perbuatan untuk mencapai tujuan tertentu.

Fungsi motivasi sebagai pendorong usaha dalam mencapai prestasi, karena seseorang melakukan usaha harus mendorong keinginannya, dan menentukan arah perbuatannya kearah tujuan yang hendak dicapai. Dengan demikian siswa dapat menyeleksi perbuatan untuk menentukan apa yang harus dilakukan yang bermanfaat bagi tujuan yang hendak dicapainya. Motivasi belajar dapat diklasifikasikan menjadi dua yaitu motivasi instrinsik (keadaan yang berasal dari dalam diri siswa sendiri yang dapat mendorongnya melakukan tindakan belajar) dan motivasi ekstrinsik (keadaan yang datang dari luar individu siswa yang mendorongnya untuk melakukan kegiatan belajar).

Menurut Uno (2016:4) motif intrinsik yaitu motivasi yang timbulnya tidak memerlukan rangsangan dari luar karena memang telah ada dalam diri individu sendiri. Sedangkan motif ekstrinsik adalah motivasi yang timbul karena adanya rangsangan dari luar individu. Dalam motivasi belajar ini ada enam faktor pendukungnya Gage \& Berliner (Winarni. M, dkk 2006: 2) diantaranya: Pertama, faktor minat individu yaitu semakin tinggi minat anak terhadap yang dipelajari, maka ia akan semakin tekun mempelajarinaya. Kedua, faktor kebutuhan individu yaitu semakin individu merasa membutuhkan sesuatu yang sedang dipelajari, maka ia akan semakin tekun mempelajarinya. Ketiga, faktor penilaian individu yaitu semakin individu merasakan arti penting dari sesuatu yang sedang dipelajari baginya, maka ia akan semakin tekun mempelajarinya. Keempat, faktor sikap individu yaitu semakin positif sikap individu terhadap sesuatu yang sedang dipelajari, maka ia akan semakin senang mempelajannya. Kelima, faktor aspirasi individu yaitu semakin besar aspirasi individu untuk mencapai prestasi tinggi dalam bidang yang dipclajarinya sekaran maka ia akan semakin gigih dalam belajarnya. Terakhir, faktor insentif yaitu semakin tinggi insentif yang dirasakan oleh individu dari sesuatu yang dipelajarinya, maka ia akan semakin kuat mempelajarinya.

\section{Metode Penelitian}

Pendekatan yang digunakan adalah pendekatan kuantitatif dengan metode korelasi. Menurut Azwar (2011: 5) "Pendekatan kuantitatif adalah penelitian yang analisisnya lebih fokus pada data-data numerikal (angka) yang diolah dengan menggunakan metode statistika. Pada umumnya penelitian menggunakan pendekatan kuantitatif merupakan penelitian sampel besar, karena pada pendekatan kuantitatif dilakukan pada penelitian inferensial yaitu dalam rangka pengujian hipotetsis dan menyandarkan kesimpulan pada suatu probabilitas kesalahan penolakan hipotesis nihil. Dengan menggunakan pendekatan ini, maka akan diperoleh signifikansi hubungan antar variabel yang diteliti". Adapun pengetian dari metode korelasi diungkapkan oleh Faenkel dan Wallen (2008: 328) adalah suatu penelitian untuk mengetahui hubungan dan tingkat hubungan antara dua variabel atau lebih tanpa ada upaya untuk mempengaruhi variabel tersebut sehingga tidak terdapat manipulasi variabel Penelitian korelasi ini bertujuan untuk menemukan ada tidaknya hubungan dan apabila ada, berapa eratnya hubugan serta berarti atau tidak hubungan ini.

Penelitian ini dilaksanakan pada semester genap tahun pelajaran $2018 / 2019$, tepatnya pada bulan Januari sampai dengan Mei tahun pelajaran 2018/2019. Populasi dalam penelitian ini adalah seluruh siswa kelas V Sekolah Dasar di Gugus Nagasari Kecamatan Karawang Barat berjumlah 571 siswa. Sampel dalam penelitian ini menggunakan Simple Random Sampling karena pengambilan anggota sampel dari populasi dilakukan secara acak tanpa memperhatikan strata yang ada dalam populasi tersebut. Adapun Sampel dari penelitian ini 
adalah seluruh siswa kelas V di SDN Nagasari IV dan SDN Nagasari VI Gugus Nagasari Kecamatan Karawang Barat yang berjumlah 85 siswa.

Teknik pengumpulan data dalam penelitian ini menggunakan dengan menggunakan instrumen angket variabel motivasi belajar dan instrumen angket variabel keterampilan sosial. Teknik analisis data yang digunakan yaitu statistik deskriptif, ukuran statistik deskriptif dapat digolongkan menjadi dua kelompok, yaitu ukuran nilai tengah dan ukuran deviasi. Ukuran nilai tengah terdiri dari rata-rata (mean), median, dan modus. Sedangkan ukuran deviasi terdiri dari varians, simpangan baku, koefisien variasi, dan nilai jarak (range). Yang kedua menggunakan statistik inferensial yang terdiridari uji normalitas, uji homogenitas, dan uji hipotesis.

\section{Hasil dan Pembahasan}

Data penelitian tentang keterampilan sosial siswa bersumber dari skor jawaban yang diberikan siswa terhadap pernyataan-pernyataan yang tertuang dalam angket keterampilan sosial siswa. Variabel keterampilan sosial terdiri atas 5 indikator, yaitu: (1) Berinteraksi dengan teman sebaya; (2) Bekerja sama dengan teman dalam pembelajaran; (3) Siswa menjadi tutor sebaya dengan baik; (4) Tidak memilih-milih teman; (5) Mau memulai komunikasi dengan teman; (6) Siswa menunjukkan empati terhadap teman.

Berdasarkan data yang diperoleh melalui tes keterampilan sosial dengan 85 responden. Pemberian skor dilakukan dengan kriteria yang sesuai dengan prosedur dan disetujui oleh pembimbing. Berdasarkan data observasi yang terkumpul diperoleh skor maksimum 126 dan skor minimum 82, rentang empirik antara 82 - 129, rata-rata 107.08, simpangan baku (SD) 11.79 , modus (Mo) 126, median (Me) 107, varian 139.05, banyak kelas 8, dan panjang kelas 6.

Sedangkan Data penelitian tentang motivasi belajar siswa bersumber dari skor jawaban yang diberikan siswa terhadap pernyataan-pernyataan yang tertuang dalam angket motivasi belajar siswa. Variabel motivasi belajar terdiri atas 5 indikator diantaranya 1) kuatnya kemauan untuk belajar, 2) adanya hasrat dan keinginan berhasil, 3) ketekunan dalam mengerjakan tugas, 4) tidak mudah putus asa, dan 5) dapat mempertahankan pendapatnya.

Berdasarkan data yang diperoleh melalui tes motivasi belajar dengan 85 responden. Pemberian skor dilakukan dengan kriteria yang sesuai dengan prosedur dan disetujui oleh pembimbing. Berdasarkan data observasi yang terkumpul diperoleh skor maksimum 130 dan skor minimum 78, rentang empiric antara 78 - 131, rata-rata 106.34, simpangan baku (SD) 14.04, modus (Mo) 113, median (Me) 111, varian 197.06, banyak kelas 9, dan panjang kelas 6.

Pengujian normalitas menggunakan metode Lliliefors, apabila hasilnya menunjukkan $\mathrm{L}_{\text {hitung }}>\mathrm{L}_{\text {tabel }}$ maka $\mathrm{H}_{\mathrm{o}}$ menyatakan bahwa sebaran skor berdistribusi normal ditolak, dan sebaliknya $\mathrm{H}_{\mathrm{a}}$ diterima. Hasil perhitungan normalitas data dari setiap variabel disajikan pada tabel sebagai berikut:

Tabel 1

Hasil Uji Normalitas

\begin{tabular}{lccc}
\hline \multicolumn{1}{c}{ Uraian } & $\mathrm{L}_{\text {Hitung }}$ & $\mathrm{L}_{\text {Tabel }}$ & Kesimpulan \\
\hline Keterampilan Sosial & 0,085 & 0,096 & Normal \\
Motivasi Belajar & 0,066 & 0,096 & Normal \\
\hline
\end{tabular}

Pengujian persyaratan analisis menunjukkan bahwa skor tiap variabel penelitian telah memenuhi persyaratan untuk dilakukan pengujian statistic lebih lanjut. Hipotesis yang 
diajukan dalam penelitian ini menyatakan bahwa terdapat hubungan positif antara keterampilan sosial dengan motivasi belajar siswa. Untuk mengetahui derajat signifikansi dan kelinearan persamaan regresi, dilakukan uji $\mathrm{F}$ dan hasilnya dapat diungkapkan pada tabel berikut ini:

Tabel 2 Rangkuman Uji Linieritas dan Signifikansi Regresi Y atas X

\begin{tabular}{ccccc}
\hline Sumber Variansi & JK & RJK & $F_{\text {Hitung }}$ & F $_{\text {Tabel }}$ \\
\hline Total & 977771 & & & \\
Regresi a & 961217.9 & & & \\
Regresi b/a & 245408.00 & 245408.00 & & \\
Residu & -228854.89 & -2757.28787 & & \\
Error & -629293475 & -7403477.646 & -3.40 & 1.711 \\
Tuna Cocok & 629064620.04 & 25162582.80 & & \\
\hline
\end{tabular}

Dari tabel di atas dapat disimpulkan bahwa perhitungan analisis regresi sederhana pada data keterampilan sosial dengan motivasi belajar siswa menghasilkan arah regresi $b$ sebesar 29,144 dan konstanta a sebesar 0,721. Dengan demikian bentuk hubungan antara kedua variabel tersebut digambarkan oleh persamaan regresi $\hat{Y}=0,721+29,144 \mathrm{X}$. Selanjutnya dilakukan pengujian korelasi dengan pearson product moment untuk mengetahui kekuatan hubungan antara ketrampilan sosial dengan motivasi belajar siswa. Kekuatan hubungan variabel $\mathrm{X}$ dengan $\mathrm{Y}$ ditujukkan dengan koefisie korelasi dan hasil uji t tersebut dapat dilihat pada tabel sebagai berikut:

Tabel 2 Koefisien Korelasi antara Keterampilan Sosial dengan Motivasi Belajar Siswa

\begin{tabular}{cccccc}
\hline Korelasi & $\mathrm{T}_{\text {hitung }}$ & $\mathrm{T}_{\text {tabel }}$ & Notasi & $\begin{array}{c}\text { Koefisien } \\
\text { Korelasi }\end{array}$ & $\begin{array}{c}\text { Koefisien } \\
\text { Determinasi }\end{array}$ \\
\hline $\mathrm{X}$ dan Y & 6,94 & 1,66 & $\mathrm{r}_{\mathrm{xy}}$ & 0,606 & 0,37 \\
\hline
\end{tabular}

Hasil dari pengujian hipotesis menunjukkan bahwa hipotesis nol yang diuji di tolak, sebaliknya hipotesis penelitian yang diajukan diterima. Hal ini terlihat dari $\mathrm{F}_{\text {hitung }}$ yang lebih besar dari $F_{\text {tabel }}$, pada taraf signifikan $\alpha=0,05$, adapun hipotesis yang diajukan adalah terdapat hubungan antara keterampilan sosial dengan motivasi belajar siswa. Hal ini dibuktikan dengan nilai $t_{\text {hitung }}>t_{\text {tabel }}$ yaitu 6,94 $>1,66$, nilai koefisien korelasi $\left(r_{x y}\right)=0,606$ dan koefisien determinasi $=0,37$. Koefisien ini teruji signifikan sehingga dapat diartikan bahwa variabel keterampilan sosial memberikan sumbangan terhadap motivasi belajar sebesar $37 \%$. Dari hasil perhitungan analisis di atas dapat disimpulkan bahwa terdapat hubungan antara variabel keterampilan sosial dengan motivasi belajar.

\section{Kesimpulan}

Berdasarkan hasil penelitian, penulis merumuskan kesimpulan sebagai berikut: Terdapat hubungan antara keterampilan sosial $(\mathrm{X})$ dengan motivasi belajar siswa $(\mathrm{Y})$ yang ditunjukkan oleh koefisien korelasi $\left(\mathrm{r}_{\mathrm{xy}}\right)=0,606$ dan koefisien determinasi $=0,37$. Hal ini menunjukkan bahwa $37 \%$ dari motivasi belajar berhubungan dengan keterampilan sosial. Dengan demikian keterampilan sosial mempunyai hubungan nyata dengan motivasi belajar. Semakin tinggi keterampilan sosial siswa, maka semakin tinggi pula motivasi belajarnya. Demikian pula sebaliknya, semakin rendah keterampilan sosial siswa, maka rendah pula motivasi belajarnya. 


\section{Daftar Pustaka}

Asy'ari, M., Ekayati, N, I., Mutalessy, A. (2014). Konsep Diri, Kecerdasan Emosi dan Motivasi Belajar Siswa: Persona Jurnal Psikologi Indonesia. 3 (1), 83-89.

Azwar, S. (2011). Metode Penelitian. Yogyakarta: Pustaka Pelajar.

Budiarto, A. (2016). Perbedaan Keterampilan Sosial Siswa Aktif dan Pasif Organisasi Kesiswaan di SMP Negeri 2 Binangun: Jurnal Riset Mahasiswa Bimbingan dan Konseling, 5 (11), $512-521$.

Cartledge \& Milburn. (1992). Keterampilan Sosial. Jakarta: Tiga Serangkai.

Emda, A. (2017). Kedudukan Motivasi Belajar siswa dalam Pembelajaran: Lantanida Journal, $5(2), 172-182$.

Fraenkel, J., Wallen, N. 2008. How to Design and Evaluate Research in Education. New York: McGraw-Hill Higher Education.

Kompri. (2015). Motivasi Pembelajaran Perspektif Guru dan Siswa. Bandung: Rosda.

Listyaningrum. (2016). Peningkatan Keterampilan Sosial Melalui Implementasi Armstrong Pada Siswa Kelas II SD Surokarsan. Jurnal PGSD 15 (5) 1.483 - 1.494.

Palupi, R., Anitah, S., Budiyono. (2014). Hubungan Antara Motivasi Belajar dan Persepsi Siswa Terhadap Kinerja Guru dalam Mengelola Kegatan Belajar dengan Hasil Belajar IPA: Jurnal Teknologi Pendidikan dan Pembelajaran, 2 (2), 157-170.

Parji, \& Andriani R. E. (2016). Upaya Peningkatan Keterampilan Sosial Siswa Melalui Permainan Tradisional Congklak: Jurnal Studi Sosial, 1 (1), 14-23.

Perdani, P. A. (2013). Peningkatan Keterampilan Sosial Melalui Metode Bermain Permainan Tradisional Pada Anak Tk B: Jurnal Pendidikan Usia Dini, 7 (2), 335-350.

Suharmini, T, dkk. (2017). Pengembangan Pengukuran Keterampilan Sosial Siswa Sekolah Dasar Inklusif Berbasis Diversity Awareness: Jurnal Penelitian Ilmu Pendidikan 10 (1), 11 21.

Suprihatin, S. (2015). Upaya Guru dalam Meningkatkan Motivasi Belajar Siswa: Jurnal PROMOSI Program Studi Pendidikan Ekonomi 3 (1), 73-82.

Suranto. (2015). Pengaruh Motivasi, Suasana Lingkungan dan Sarana Prasarana Belajar Terhadap Prestasi Belajar Siswa: Jurnal Pendidikan Ilmu Sosial, 25 (2), 11-19.

Uno, H, B. (2016). Teori Motivasi dan Pengukurannya. Jakarta: Bumi Aksara.

Winarni, M, dkk. (2006). Motivasi Belajar Ditinjau dari Dukungan Sosial Orangtua Pada Siswa SMA: Jurnal Psikologi, 2 (1), 1-5. 